\title{
Methods of Using Cases from the Life of Outstanding Mathematicians in the Training of Future Teacher
}

\author{
Oksana A. Pavlova ${ }^{1 *}$, Zulfiya F. Zaripova ${ }^{2}$, Liliya R. Zagitova ${ }^{2}$, Venera G. Zakirova ${ }^{3}$ \\ ${ }^{1}$ Kaluga State University named after K.E. Tsiolkovsky, 248023, Stepan Razin Street 26, Kaluga, RUSSIA \\ ${ }^{2}$ Almetyevsk State Oil Institute, 423450, Lenin Street 2, Almetyevsk, RUSSIA \\ ${ }^{3}$ Kazan (Volga region) Federal University, 420008, Kremlevskaya Street 18, Kazan, RUSSIA
}

Received 13 March 2021 - Accepted 13 June 2021

\begin{abstract}
An appeal to the personalistic component of the history of mathematics, stories about scientists who have contributed to its development, contribute to the implementation of the educational aspect in the teaching of mathematics. A question arises: how can a mathematics teacher shape the moral qualities of a child, including patriotic and international feelings; what pedagogical means he can use at the same time; how to prepare a teacher for this type of activity at a university. Based on the purpose of the study, the case study method was chosen as the main tool, which allowed us to carefully study the data (biographical materials) in a certain context (in terms of their educational potential). Biographies of outstanding mathematicians were analyzed and cases related to the manifestation of their qualities in various life situations were identified. The publications and experience of teachers were considered in terms of the possibility of including this material in the process of teaching mathematics. The empirical experience of implementing the process of training a teacher-educator in the framework of teaching methodological and mathematical disciplines and organizing extracurricular activities of a professional orientation was generalized. As a result, the main directions of work on the implementation of educational activities through the appeal to the patterns of behavior of the creators of mathematics were identified: the creation of biographical essays and the preparation of presentations that reveal personal experience and career trajectory; the inclusion in the discussion of the actions and facts from the life of outstanding mathematicians; the inclusion in the discussion of actions and facts from the life of these wonderful people; preparation of brief historical notes on the discoveries of Russian mathematicians of different historical periods and other near-mathematical events; making presentations, wall newspapers (traditional or interactive) or video clips, organizing mathematical holidays, etc. The practical significance of the materials of this article lies in the fact that the developed system of work, including getting to know the cases from the life of scientists in the framework of training sessions, setting practice-oriented tasks for organizing independent work of students and organizing extracurricular educational activities in the form of group projects, contributes to the formation of the future teacher's readiness to use the educational potential of cases from the life of scientists in educational work.
\end{abstract}

Keywords: training of a teacher-educator, personalities of the history of mathematics, moral education

\section{INTRODUCTION}

The changes taking place in the modern world are rapid and irreversible. The fluidity and impermanence inherent in this world are reflected in both art and literature, and are also reflected in the world-famous paintings of Salvador Dali, the books of the mathematician Lewis Carroll, etc. But even today, the problem of the values of a new world person, who is involved in the process of creating artificial intelligence and abandons traditions, who is looking for himself and does not find a foothold in the conditions of turbulence,

(c) 2021 by the authors; licensee Modestum. This article is an open access article distributed under the terms and conditions of the Creative Commons Attribution License (http://creativecommons.org/licenses/by/4.0/). 


\section{Contribution to the literature}

- The study presents a new approach based on the use of cases from the life of scientists as a tool for forming a morally-oriented picture of the world in students.

- The principles of selection and formation of cases from the life of scientists aimed at solving educational tasks are described.

- A unique methodology is proposed and forms of work with historical and mathematical content are highlighted, which stimulate the process of self-development of the personality of future teacherseducators and contribute to the formation of readiness to solve educational tasks in the context of subjectbased learning.

- The obtained data contribute to the understanding of the influence of the developed approach, associated with the use of cases from the life of scientists, on the formation of the personality of the teacher-educator.

is on the agenda (Galchenko et al., 2020; Khairullina et al., 2020).

The formation of a growing personality is facilitated by interaction with the accumulated layers of culture and science, implemented in the educational process of a comprehensive school. Both the preservation of cultural traditions and the creation of new revolutionary developments in any scientific field are the work of specific people or groups of authors. People of new generations should know how and under what conditions the birth of new knowledge took place, what was the meaning of the life of specific scientists and what guided their behavior (Potapova et al., 2018; Sirazetdinov, 2018). Only a consumer attitude to the surrounding world will lead to the degradation of society. And it is the education system and specific teachers who are responsible for the formation of morally integral personalities.

That is why the appeal to the history of the development of science, the life of its creators is considered by us as a source of forming a morally oriented picture of the world. Although we are aware that the history of science has had its own immoral acts, crimes against humanity. In this study, we will take as a basis an appeal to the history of mathematics, although the results of the study can be transferred to any field of knowledge.

Various aspects concerning the role of the history of mathematics in its teaching are considered in the work (Fauvel \& van Maanen, 2000). A large amount of research has been accumulated in this area (Clark et al., 2016), which are subject to generalization and rethinking at a new stage in human development in connection with possible global threats. A mathematics teacher should think not only about the development of students' thinking but also about their moral education as citizens of a single world (Sabirova et al., 2019; Savvina \& Melnikov, 2019). An appeal to the personalistic component of the history of mathematics, stories about scientists who contributed to its development, contribute to the implementation of mathematics education (Drobyshev et al., 2017).
At the same time, the volume of material from the history of mathematics and biographical information about mathematicians is still insignificant in textbooks on mathematics (Drobyshev \& Drobysheva, 2020). This circumstance and the requirement to describe educational activities in integration with the content of subject areas in the work programs of education from September 1, 2021 initiates the search for relevant tools for implementing educational work and forming the readiness of the future teacher to use them in practice.

The problem of forming the teacher's readiness to carry out educational work through an appeal to the moral potential of the scientist's personality became the subject of research (Pavlova, 2008), but it requires reflection in new conditions: the globalization of world processes, reducing the classroom load of students and increasing the share of independent work; practice orientation of training; the importance of the role of an individual's activity in their professional development and the search for mechanisms to stimulate this process.

\section{Purpose and Objectives of the Study}

The purpose of the study is to identify the possibilities of using cases from the life of mathematicians to form the personal and professional qualities of a future teacher-educator. The results of the study will allow us to systematically consider the possibilities of this type of case for mastering fundamentally new professional knowledge and skills and improving existing knowledge and skills in the pedagogical field. Questions arise: how a teacher who teaches mathematics can form the moral qualities of a child, including patriotic and non-national ones; what pedagogical means he can use in the classroom and extracurricular activities; how to implement educational work to the personality of the student (future teacher) and his preparation for this type of activity in the conditions of studying at a university.

\section{LITERATURE REVIEW}

The historical and mathematical training of the future teacher became the subject of research (dos Santos, \& 
França, 2020; Drobyshev, 2010, 2011, 2018; Gulnaz \& Fatima, 2019; Hokor, 2020; Izmirli, 2020; Khusnutdinova \& Gumerova, 2019; Mendes, 2020; Pyrkov, 2019; Romanov, 2012; Sudakova et al., 2017; Valeeva \& Bushmeleva, 2016). The importance of turning to the life of the personalities of the creators of mathematics for solving educational problems was noted by mathematicians (Bobynin, 1913; Khinchin, 1963; Shidlovsky, 1912; Shokhor-Trotsky, 1892; Tavartkiladze \& Vilenkin, 1985; etc.). Researchers identify the following areas of using biographical information: education of patriotism, international education (Beloborodova, 1999; Khinchin, 1963; Kozhabaev, 1988; etc.), the formation of respect for work and a sense of responsibility, the formation of strong-willed personality traits (Beloborodova, 1999; Bolgarsky, 1944), demonstration of the necessary qualities of a creative personality (Shabashova, 1995).

Biographies of scientists of the past and present became the subject of interest of the next generations. F. Arago published biographies of great astronomers (29 magnificent portraits from Hipparchus to Laplace), physicists, and geometers (Gaspard Monge, Joseph Fourier, etc.). The descriptions pay attention not only to scientific works but also to the formation of the personality, pedagogical and social activities of outstanding scientists. The works of various authors provide information about the professionals in Russian education in the field of natural science (Mendeleev, etc.) and mathematics (Lobachevsky, Ostrogradsky, Mordukhai-Boltovsky, Chebyshev, etc.).

Panisheva (2010) analyzed the biographies of more than 30 mathematicians of the past and present. Having systematized the facts from the life of famous mathematicians, she was able to identify several significant areas of the educational potential of biographical information: persistence in studies, independent acquisition of knowledge (Nicolo Tartaglia, Ramunajan, Pierre Fermat); decisiveness, determination (Blaise Pascal, Sophia Kovalevskaya, Sophia Germain, Leonard Euler, Lev Pontryagin, Niels Abel); endurance, scientific courage, courage, heroism (Niels Abel, Evarist Galois, Paolo Valmes, Andrey Kolmogorov, etc.); active citizenship (Euclid, Bernard Bolzano, Mikhail Ostrogradsky); sensitivity, humanity, disinterestedness (Henri Poincaré, Niels Abel), as well as modesty, breadth, and versatility of interests, patriotism.

Studies of the life of scientists in different subject areas in general and the factors of their personal and professional development reflect the need for people to approach their experience, to understand the nature of genius. Biographical information is difficult for students to understand. Acquaintance with individual episodes from the life of a scientist (cases) is more relevant. That is, a case is a real case from the life of a scientist, which deals with some important aspects that are directly related to the solution of educational problems.
Cases from the life of scientists should be distinguished from professional-pedagogical cases (Kozyreva, Kozyrev, \& Bokova, 2016) and methodological cases (Chirkova \& Pavlova, 2021). Although many of them can be used in the training of a teacher-educator.

Drobyshev, Drobysheva, and Taras (2017) share the opinion of A. Einstein: the only thing that can guide us to noble thoughts and actions is the example of great and morally pure personalities. In their work, the authors presented episodes from the life of scientists to discuss moral issues with students. The researchers believe that the initial acquaintance started in the classroom will continue.

Here is an example of such story. "N.I. Lobachevsky often visited a shop in Kazan, where paintings were exhibited and one could buy musical notebooks. In it he noticed a young clerk, constantly engaged in some calculations. Noting this feature and his penchant for mathematics, Nikolai Ivanovich asked if he had any interest in studying. It turned out that the child was brought by the owner from Italy and was an orphan, but has a desire for knowledge. Subsequently, the little Italian was admitted to the gymnasium, then graduated from the university, where he later began to teach physics. We are talking about Professor I. A. Boltsani."

In this and other cases, many layers can be hidden (breadth of interests-in addition to mathematics, interested in pictures and notes; attention to detail, perspicacity; sensitivity and responsiveness, etc.; as well as the ratio of random and our efforts in our selfdevelopment).

How can we implement the teacher's training for educational work based on the use of case studies? The author's courses are considered as one of the means of training a teacher-educator. The purpose of this course is to form the historical and mathematical competence of future teachers. The main educational tool is research projects aimed at shaping the experience of using elements of the history of mathematics to solve educational problems (Drobyshev, 2013), and tasks aimed at developing skills for the implementation of creative educational activities (Pavlova, 2008). At the same time, the author's course cannot solve the problem of training a teacher-educator. The focus on training a teacher-educator should be traced both in the content of academic disciplines and in the organization of extracurricular work.

\section{METHODOLOGY}

Based on the purpose of our research, we have chosen case studies as the main toolkit for our work.

At the first stage of our experiment, biographies of outstanding mathematicians were analyzed and cases related to the manifestation of the qualities of a famous person in various life situations were identified. The publications and experiences of teachers were reviewed 
and reinterpreted in terms of the possibility of including this material in the teaching of mathematics and in the process of preparing a future teacher-educator. A diagnostic cross-section was conducted, aimed at identifying the knowledge of famous mathematicians among first-year students (future teachers).

At the second stage, there was an understanding of the principles of selecting material for cases and the principles underlying the inclusion of this material in the educational process. It was found that the selection of material for the case should be based on the following principles: accessibility of the perception of the case by students - the content of the case should be adapted to age characteristics (should not injure the child's psyche, if we are talking, for example, about younger schoolchildren), as well as the intellectual needs and capabilities of students (stories about events and phenomena that they are able to understand); emotional saturation - the plot of the case should be convincing and emotionally rich. The information is presented in a way that touches the students ' feelings.

The use of case studies will contribute to the solution of educational tasks, if you follow the principles when applying to them:

Leading idea - any case is offered for discussion to realize its educational potential;

Purposefulness - discussion of a fact or deed allows one to make an unambiguous conclusion about the essence of the analyzed phenomenon - a certain universal value;

Organicity - the case should be addressed naturally. This is possible if the plot of the case proposed for discussion is directly related to the material being studied (the scientist is the author of a mathematical theory, a nominal theorem is studied, etc.), is built into the plot of the problem, or corresponds in content to current events in the life of students (organization of a mathematical holiday dedicated to some event or scientist, etc.);

Multiple - return to the case is ensured in new situations, since the same case and the idea embedded in it are not fixed in the minds of students when they turn to it once. Either the same idea is transmitted through the content of several cases reflecting the life and work of mathematicians from different countries of the world;

Variability - each new experience of interaction with cases occurs in a different form (sign-symbolic, figurative-spatial, or research historicization (Pavlova, 2016)) or at a different level of independence (passive perception of the case and the opinions of other participants in the discussion about it; expressing one's opinion on the content of the case; search for information for a new case; designing the case and presenting it to other students as a reason for discussion).

At the third stage, a methodological system was designed and implemented in the process of training future teachers, which involves working on their awareness of the educational potential of cases from the life of scientists and the principles underlying their formation and presentation. The tools used in the framework of this methodological system (acquaintance with cases from the life of scientists in the framework of training sessions, setting practice-oriented tasks for organizing independent work of students, organizing extracurricular educational activities in the form of group projects) are aimed at forming the personality of the teacher-educator.

The effectiveness of the developed methodological system is ensured by compliance with a set of pedagogical conditions:

The readiness of a higher school teacher to implement this type of work, which means they need for his professional self-development (Burlakova, Bogatyreva, \& Pavlova 2020) in this area. The axiological component of readiness is the awareness of the importance of the implementation of educational work in the process of teaching academic disciplines; content component organization of seminars and conferences on the research problem, exchange of developed cases; activity component - building up practical experience of working with cases in teacher training;

Use of the resource potential of the educational environment of the university (the availability of resources of electronic library systems; the ability to exchange information through the information and educational environment of the university, etc.);

Designing a system of extracurricular educational activities of professional orientation and their implementation by the joint efforts of students and teachers in the form of educational events (a scheduling system to well-known national and world memorable dates and holidays, anniversaries from the history of science);

Taking into account the opinions and wishes of students when designing a new educational event;

Voluntariness of students in choosing their contribution to joint projects, relying on their interests and inclinations when choosing a direction of work;

Taking into account regional and national components when designing a system of educational work, etc. (priority in getting to know the personalities of the region and the country of residence of students).

We consider cases from the life of scientists from the point of view of their acmeological and axiological values, hidden in their content and revealed in the process of training a teacher-educator. 
Table 1. Examples of cases from the life of outstanding mathematicians

\begin{tabular}{|c|c|c|}
\hline Case1 & $\begin{array}{l}\text { Ivan } \\
\text { Georgievich } \\
\text { Petrovsky (1901- } \\
\text { 1973) }\end{array}$ & $\begin{array}{l}\text { Ivan did not feel much interest in mathematics because of the formal approach to its teaching and } \\
\text { made his choice in favor of biology. However, after accidentally reading a book on Dirichlet number } \\
\text { theory, he wanted to learn more about it. At the same time, he did not master the next book on } \\
\text { mechanics by N. E. Zhukovsky, since he did not have enough knowledge to read it. The future famous } \\
\text { mathematician makes a new decision - to study mathematics. }\end{array}$ \\
\hline Case 2 & $\begin{array}{l}\text { Pavel Sergee } \\
\text { Alexandrov } \\
(1896-1982)\end{array}$ & $\begin{array}{l}\text { Pavel Sergeyevich studied several languages from early childhood, but he could have difficulties } \\
\text { solving mathematical problems. Starting to study the theory of parallel, the teacher A. R. Eiges so } \\
\text { masterfully conducted an excursion into the history of the creation of imaginary geometry that it } \\
\text { amazed the young student. Since then, geometry has become a magical world for him, which he was } \\
\text { immensely passionate about, and it was mathematics that later became his profession. }\end{array}$ \\
\hline Case 3 & $\begin{array}{l}\text { Francois } \\
(1540-160\end{array}$ & $\begin{array}{l}\text { As a young officer and having an interest in mathematics, F. Viet, through mathematical reasoning, } \\
\text { found the key to the cipher used by the Spanish King Philip II during correspondence. The code was } \\
\text { incredibly complex, and the ruler had no doubt that no one in the world would be able to decipher it. } \\
\text { Subsequently, Philip was sure that the French had resorted to witchcraft, and Viet was thus able to } \\
\text { help his fatherland. }\end{array}$ \\
\hline Case 4 & $\begin{array}{l}\text { Isaa } \\
(164\end{array}$ & $\begin{array}{l}\text { Newton said that as a child he was a poorly performing and physically weak student. He was able to } \\
\text { make serious efforts to study and become the first as a result of revenge for the pain he suffered from a } \\
\text { physical conflict with a classmate. }\end{array}$ \\
\hline Case 5 & $\begin{array}{l}\text { Paph } \\
\text { Lvov } \\
\text { Cheb } \\
(1821\end{array}$ & $\begin{array}{l}\text { Being a mathematician and professor, Paphnutiy Lvovich managed resources sparingly and easily } \\
\text { increased his capital. However, when making transactions, he never went against his conscience. So } \\
\text { faced with a situation where the children of the Goryainov family were left without means of support, } \\
\text { and Chebyshev learned that he had acquired this property, he immediately returned the entire estate to } \\
\text { the owners. }\end{array}$ \\
\hline Case 6 & $\begin{array}{l}\text { Leonhard Euler } \\
(1707-1783)\end{array}$ & $\begin{array}{l}\text { The life of this mathematician, a Swiss by birth and who by chance came to Russia, was completely } \\
\text { devoted to the service of mathematics and the state interests of the new fatherland. He performed his } \\
\text { duty to them with complete dedication and dedication (the case of the loss of vision) and left behind a } \\
\text { legacy that still becomes a source of inspiration for mathematicians of new generations. }\end{array}$ \\
\hline
\end{tabular}

\section{RESULTS}

Analysis of biographical material from the lives of mathematical scientists (our contemporaries) showed that often different factors influence the emergence of their interest in mathematics: knowledge gleaned from books that came to hand in time (Case 1 of Table 1), stories from the lives of mathematical scientists told by teachers (Case 2 of Table 1), etc.

In turn, the research conducted by us for more than 10 years shows that in the semantic field of "mathematics" the names of mathematical scientists are quite rare.

This was established as follows. In the first classes in mathematics, students of the first year of study of the Institute of Pedagogy of KSU named after K.E. Tsiolkovsky within five minutes must write 20 wordsassociations with mathematics. Purpose: actualization and systematization of mathematical concepts that students own. During the discussion of the recorded words, it is possible to repeat a large circle of mathematical and near-mathematical concepts (types of

In general, the educational potential of cases describing some episodes from the life of mathematical scientists or their actions consists in the following: to get into the content of universal values and moral principles underlying decision-making in specific situations; to understand the nature of patriotic and civic feelings in connection with the processes of globalization; to see numbers, arithmetic operations, one-dimensional, twodimensional, and three-dimensional geometric figures, functions, sections of mathematics, mathematicians, etc.). At the same time, the frequency of mentioning the names of scientists is very limited (no more than $1 \%$ ) and is usually predetermined precisely by stable turns: "Pythagoras 'theorem", "Thales' theorem", "Vieta's theorem". Students of the first year of study know almost nothing about the scientists themselves, although by joint efforts they manage to recall the names of several more scientists (Aristotle, Euclid, Plato, Newton, Tsiolkovsky, etc.). When asked: do you know women mathematicians, students remember S.V. Kovalevskaya. This means that school teachers tell cases from the life of famous mathematicians, even if they are not remembered by the students.

The set of cases-episodes from the life of mathematical scientists-is unlimited (Table 1). At the same time, the relevance of these educational tools should be ensured by their scientific basis and variability, as well as by the activity of the students themselves in the organized educational events.

how the strong-willed qualities of the individual are manifested; to form respect for work, a sense of responsibility and active citizenship; to demonstrate the qualities of a creative person (Pavlova, 2008).

In the process of preparing a future teacher-educator at a university, its dialectical nature is manifested. The need to prepare future teachers for educational work is 
combined with the need to provide educational influences on the student himself. The upbringing of students can be carried out through cases from the life of mathematicians, educators, mathematicians, authors of popular science, and educational-methodical literature in mathematics.

Thus, a case study in the training of a teachereducator involves a discussion of a specific episode from the life of a scientist, carried out with the aim of an educational impact on students. At the same time, the systematic use of this tool in the process of preparation at the university creates the prerequisites for the formation of a student's readiness to use it in professional activities.

The principles and pedagogical conditions identified in the course of the theoretical analysis, aimed at using cases from the life of scientists in the training of a teacher-educator, are also confirmed by the practice of using this technology in the training of future teachers.

For more than 10 years, teachers of disciplines of methodological and mathematical orientation have been implementing a system of work to reveal the educational potential of cases from the life of scientists, including:

\section{Acquaintance with Cases from the Life of Scientists in the Framework of Training Sessions}

These cases are voiced by the teacher. In this way, he simultaneously has an educational effect on students and sets an example of how stories from the lives of scientists can be built into the educational process. One case can be voiced for different reasons and in different situations. To include a specific case, an information lead is used - a kind of educational situation that has direct or indirect connections with the case.

In the process of studying at the university, within the framework of academic studies, students come across the names of L. Euler (Euler circles), J. Peano (Peano's axioms), they also have the opportunity to learn more about the creators of set theory (Cantor and Dedekind), mathematical logic (Boole and Peano), geometry (Euclid and Lobachevsky), etc. But this work does not happen by itself but is directed by the teacher. He can tell some instructive story himself, having a significant reason for that (study of educational material related to a given scientist), or offer students to prepare historical information about the life of a scientist.

An informational lead for referring to a certain case may also be "artificial". For example, a student has not completed his homework, and the teacher expresses his opinion about the situation, referring to a fact from the life of L. Euler, who, having performed complex computational calculations in a short time, put his vision in danger. The main goal is to touch the emotions of students and stimulate the formation of their own opinions about two events (related to students and from the life of a scientist). Seeing the interest in the eyes of students, this fact can be supplemented with other details (how Euler got to Russia, what rich scientific heritage he left to descendants, etc.).

Later, encountering elements of graph theory in class, the teacher reminds students of L. Euler, its creator. A one-time reference to a certain instructive story is most often not preserved in the student's memory so that he could reproduce this story on his initiative. It is possible to reproduce the same story in several situations; asking students to remember the story itself (case) without recalling its content; providing the opportunity to highlight and explain the possible educational potential of the case in working with younger students. All of the above is preparatory work so that future teachers can apply this ready-made case to work with younger students. This work stretches over several academic years.

Chirkova (2019) notes the names of B. Pascal, P. Fermat, L. Euler, N.I. Lobachevsky should not be left without attention; in extracurricular work, acquaintance with the life and work of the creators of mathematics should be continued.

\section{Statement of Practice-oriented Tasks for the Organization of Students' Independent Work}

The teacher formulates appropriate practice-oriented tasks for students in relation to the content of academic disciplines: prepare a historical reference about a mathematical discovery (who made this discovery and when, what is interesting about this person), prepare a presentation with information from the life of a scientist who is related to the material being studied; create a task that presents materials from the life of a particular mathematician (first on a sample, and then independently); select questions for a quiz, etc. (Pavlova, 2018).

Not all tasks are related to the design of cases from the life of scientists, but they all contribute to the acquisition of experience with the historical and mathematical literature as a source of information and experience in the design of educational work based on an appeal to the history of mathematics.

Depending on individual preferences, students can present their work in sign-verbal (in the form of oral and written messages of various types), figurative-spatial (in the form of structural diagrams, drawings and models; presentations and posters, both real and interactive; pages on the Internet or social networks) and subjectpractical form (in the form of research with subsequent publication of the results obtained, a speech at a conference, or with obtaining a real or virtual product a case, a quest, a visual model, a three-dimensional calendar, etc.) (Pavlova, 2018). 


\section{Organization of Extracurricular Educational Activities in the Form of Group Projects of Pedagogical Orientation}

A professionally oriented pedagogical project is a project that ensures the formation of professional competencies of a future teacher in the field of subject methods, which is based on the creation and implementation of an image of solving pedagogical problems correlated with the main directions of methodological work and the specifics of the academic subject (Pavlova \& Chirkova, 2020).

Every year at the Institute of Pedagogy on March 14, the mathematical holiday "Pi Day" is held. Each time it goes the way the students themselves want to organize it. It is important to use exactly the format that students are interested in and which they are ready to implement. On this day we hold quizzes, sing math songs, bake pies, etc. At the same time, it is relevant on this day to remember the life and work of such scientists as A. Einstein (on this day he was born) and S. Hawking (on this day he died). It is not for us to judge whether it is an accident or not. But this deserves our attention. Students themselves choose cases from the life of these scientists, which they would like to discuss.

The textbook plays an important role in teaching mathematics. In the classroom and as part of independent work, students analyze textbooks on mathematics for elementary school by different authors (more than 10 educational sets). The project, dedicated to the first Russian textbook on Arithmetic and its author Leonty Filippovich Magnitsky, allows you to simultaneously form competencies related to the analysis of textbooks and the implementation of educational work based on cases (Chirkova, 2020). During the project, students get acquainted with the history of the creation of Arithmetic, realize the role of this book in the development of domestic mathematics and the methods of teaching it. At the same time, we are considering several cases from the life of Leonty Filippovich Magnitsky (at birth he bore the surname Telyashin). One of them explains how, from whom, and for what he got his nickname Magnitsky (from "magnet", that is, a person who attracts to himself). Biographical information from the life of the first author of the textbook in Russia is presented in the works of O.A. Savvina (2019) and other authors.

Various memorable dates from the history of mathematics and mathematics education are embodied in new projects "The Day of Entertaining Mathematics" (cases related to life with Yakov Isidorovich Perelman the father of "entertaining science"); "Kaluga region - a forge of scientific personnel" (discussion of cases from the life of scientists associated with the Kaluga region: Pafnuti Lvovich Chebyshev, Alexander Yakovlevich Khinchin, Sofya Vasilievna Kovalevskaya, Konstantin Eduardovich Tsiolkovsky, Alexander Yakovlevich
Chizhevsky, Vladimir Alexandrovich Ilyin, Dmitry Petrovich Konstantin Faddeev). To create an emotional background, students recite poems written by mathematicians (!) And about mathematicians. In further work, the accumulated cases are transformed into stories for younger students or used as a basis for text and non-standard tasks. Let us give examples of problems in which we are talking about mathematicians - our fellow countrymen.

(1) The famous Russian mathematician Alexander Yakovlevich Khinchin was born and lived as a child in the city of Kondrovo. He lived 65 years. In the twentieth century, he lived 53 years longer than in the nineteenth century. What year was Alexander Yakovlevich born? (Olympiad for junior schoolchildren, Kaluga, 2002)

(2) The famous Russian scientist K.E. Tsiolkovsky lived years. In the __entury, he lived _ years less than in the century. In what year was K.E. Tsiolkovsky born? (Layout of the problem for filling it out by younger students)

The life and creative activity of the Russian teachermathematician, specialist in the history of mathematics Viktor Viktorovich Bobynin is reflected in the research of Drobyshev and Drobysheva (2019). Students from the Tula region show their desire and represent their fellow countrymen.

In general, the system of work is aimed at developing the ability to design educational cases independently. The results of student participation in projects are subject to assessment in the form of certificates of commendation and diplomas, using the point-rating system. Observations of the dynamics of students ' development throughout all 5 years of study show that the necessary skills in selecting materials for cases and its inclusion in various forms of work are formed in due measure.

\section{DISCUSSION}

The work on the implementation of the developed methodological system has been carried out by us for several years, and this is the author's own initiative of the developed system. Generations of students follow each other, bringing their own vision and experience. The projects dedicated to the creator of the "imaginary" geometry Nikolai Ivanovich Lobachevsky (Polyakova, 2017), the keeper of the keys to the "kingdom of ingenuity" Emelyan Ignatievich Ignatiev (Melnikov \& Savvina, 2019) and many other remarkable scientists have not yet been implemented. New ideas hang in the air and can be born at any time. The difficulties are only related to the overload of both students and teachers.

Similarly, the work of a teacher at school on the use of cases from the life of scientists is reduced only to his personal interest and responsibility. The teacher's workload (reporting documentation, maintaining an electronic record-book, preparing for control sections, etc.) does not allow him to show his creativity in 
educational work. The experience of communication with practicing teachers shows that having an interest in the stated topic, they can not allocate time for organizing extracurricular activities of students aimed at getting acquainted with cases from the life of scientists. In turn, on the pages of textbooks, facts from the history of mathematics, portraits of scientists and facts about them are catastrophically rare (Drobyshev \& Drobysheva, 2020).

Recently, our country has adopted regulatory documents that set new tasks for teachers and teachers of higher education. Educational work should accompany the teaching of all academic subjects at school and academic disciplines at the university. As a result, the materials of this study can show the direction that can be used to organize educational influence by means of the taught disciplines, namely, by referring not only to cases from the lives of scientists, but also poets, writers, artists, etc.

\section{CONCLUSION}

Case technologies are currently considered an effective pedagogical tool. The study confirms that turning to cases from the life of scientists allows you to demonstrate the moral and volitional qualities of a person, to have a stimulating effect on the moral needs of students, the willingness to work for the benefit of society, and the formation of oneself as a person. This is equally relevant in teaching schoolchildren and in preparing future teachers.

When selecting material for a case, several principles should be observed: the leading idea, the accessibility of the perception of the case by students, purposefulness, emotional saturation, organicity, repetition, and variability. A case study in the training of a teachereducator involves a discussion of a specific episode from the life of a scientist, carried out with the aim of an educational impact on students.

The system of work to form the readiness of the future teacher-educator to use cases in work practice includes acquaintance with cases from the life of scientists in the framework of training sessions; setting practice-oriented tasks focused on working with cases for organizing students' independent work; organization of extracurricular educational activities in the form of group professionally-oriented pedagogical projects.

To include cases in the educational process, you should use the possibilities of educational sessions (use any informational guide: the connection of the scientist with the educational material or the actions of the students themselves) and extracurricular activities (organization of the event space - mathematical holidays dedicated to events from the history of mathematics and implemented in the form of group projects). Participation of students in the organization of educational events should be active, but voluntary. When designing cases, students should proceed only from their interest in the scientist and try to independently highlight the instructive facts from his biography.

The use of sign-symbolic, figurative-spatial, and subject-practical forms of historicization in the process of working with cases provides stimulation of professional self-development, both as a teacher of a higher school and as a future teacher-educator.

Author contributions: All authors have sufficiently contributed to the study, and agreed with the results and conclusions.

Funding: This paper has been supported by the Kazan Federal University Strategic Academic Leadership Program.

Declaration of interest: No conflict of interest is declared by authors.

\section{REFERENCES}

Beloborodova, S. V. (1999). Professional and pedagogical orientation of the historical and mathematical training of a teacher of mathematics in a pedagogical university (PhD thesis). MCPU, Moscow.

Bobynin, V. V. (1913). Aims, forms and means of introducing historical elements into the course of mathematics in secondary school. In Proceedings of the 1st All-Russian Congress of Teachers of Mathematics (pp. 129-143). St. Petersburg: North.

Bolgarsky, B. V. (1944). Elements of the history of mathematics in the Soviet high school (PhD thesis). KU, Kazan.

Burlakova, I., Bogatyreva, S., \& Pavlova O. A. (2020). Ways to form a teacher's professionalism. SHS Web of Conferences. International Scientific and Practical Conference "Teacher Professionalism: Psychological and Pedagogical Support of a Successful Career" (ICTP 2020), 00107. https://doi.org/10.1051/shsconf/ 20208700107

Chirkova, N. I. (2019). Self-development of student's personality by means of extracurricular work (on example of methodological mathematical disciplines). Kaluga University Bulletin. Series 1. Psychological sciences. Pedagogical Sciences, 4(5), 2429.

Chirkova, N. I. (2020). The possibilities of arithmetic L.F. Magnitsky in stimulating professional selfdevelopment of future teachers. Specialized School, 8(2), 23-30. https://doi.org/10.12737/1998-07442020-23-30

Chirkova, N. I., \& Pavlova, O. A. (2021). Methodical case as a variable means of teacher professional training. Humanization of Education, 1, 19-31. https:// doi.org/10.24411/1029-3388-2020-10146

Clark, K., Kjeldsen, T., Schorcht, S., Tzanakis, C., \& Wang, X. (2016). History of mathematics in 
mathematics education. Recent developments. History and Pedagogy of Mathematics. Montpellier.

dos Santos, E. S. C., \& França, D. M. (2020). Knowledge of "Pre mathematics" in times of the modern mathematics movement (1960-1980). Pedagogical Research, 5(3), em0071. https://doi.org/10.29333/ pr/8282

Drobyshev, Yu. A. (2010). Principles of historical and mathematical training of future mathematics teachers. Pedagogy, 9, 61-64.

Drobyshev, Yu. A. (2011). Multilevel historical and mathematical training of the future teacher of mathematics (PhD thesis). MCPU, Moscow.

Drobyshev, Yu. A. (2013). On the setting of the course "Educational aspects of the history of mathematics". Bulletin of the Tula State University. Humanities, 3-2, 81-91.

Drobyshev, Yu. A. (2018). Formation of readiness of bachelors - future teachers of mathematics for the implementation of the section "Mathematics in Historical Development". Continuum. Mathematics. Computer Science. Education, 4(12), 53-58.

Drobyshev, Yu. A., \& Drobysheva, I. V. (2019). About V. $\mathrm{V}$. Bobynin's contribution to the theory and practice of teaching mathematics on the basis of genetic method. In Actual problems of teaching mathematics. Interuniversity collection of scientific papers dedicated to the 170th anniversary of the birth of V.V. Bobynin (pp. 26-35). Kaluga.

Drobyshev, Yu. A., \& Drobysheva, I. V. (2020) Historical and mathematical component in mathematics textbooks for grades 5-6. Bulletin of the Krasnoyarsk State Pedagogical University. V.P. Astafieva, 3(53), 2739. https:/ / doi.org/10.25146/1995-0861-2020-53-3218

Drobyshev, Yu. A., Drobysheva, I. V., \& Taras, O. B. (2017). Education of personal qualities of students: materials of the personalistic component of the history of mathematics. LLC "TRP".

Fauvel, J., \& van Maanen, J. (2000). History in mathematics education, ICMI Study (New ICMI Studies Series, vol. 6), new ICMI Study Series. Springer.

Galchenko, N. A., Shatskaya, I. I., Makarova, E. V., Kulesh, E. V., Nizamutdinova, S. M., Yudina, A. M. \& Skutelnik, O. A. (2020). Student hood spiritual needs in self-isolation period: Features and ways to meet them. EurAsian Journal of BioSciences, 14(1), 2229-2234.

Gulnaz, M., \& Fatima, R. (2019). A study of finding the reasons of not choosing mathematics at senior secondary level by girls in Nawada District of Bihar. Pedagogical Research, 4(4), em0043. https:// doi.org/10.29333/pr/5899

Hokor, E. K. (2020). Pre-service teachers' probabilistic reasoning in constructivist classroom. Pedagogical
Research, 5(2), em0053. https://doi.org/10.29333/ pr $/ 7838$

Izmirli, I. M. (2020). Some reflections on the philosophy of mathematics education: A denunciation of the time and content arguments. Pedagogical Research, 5(2), em0056. https:// doi.org/10.29333/pr/7854

Khairullina, E. R., Shubovich, M. M., Bogdanova, V. I., Slepneva, E. V., Mashkin, N. A., \& Rodyukova, T. N. (2020). Modern student youth civic identity: Political activity or social responsibility? Opcion, 36(Special Edition 27), 1703-1717.

Khinchin, A. Ya. (1963) Pedagogical articles. APS RSFSR.

Khusnutdinova, R. R., \& Gumerova, M. M. (2019). Information \& educational environment - new format of interaction in a «teacher-student» system: Health-saving aspect. Vestnik NCBŽD, 1(39), 54-58.

Kozhabaev, K. G. (1988). On the educational orientation of teaching mathematics at school. Enlightenment.

Kozyreva, O. A., Kozyrev, N. A., \& Bokova, E. V. (2016). Professional pedagogical case in the structure of personality self-realization and reflection. Electronic multidisciplinary scientific journal with a portal of international scientific and practical conferences Internet Science, 10, 364-378.

Melnikov, R. A., \& Savvina, O. A. (2019). Keeper of the keys to the kingdom of ingenuity (to the 150th anniversary of Yemelyan Ignatievich Ignatiev). Mathematics at school, 7, 75-80.

Mendes, I. A. (2020). History for the teaching of mathematics: Transformation and mobilization of mathematical knowledge for school. Pedagogical Research, 5(3), em0072. https://doi.org/10.29333/ $\mathrm{pr} / 8284$

Panisheva, O. V. (2010). Educational possibilities of personification of mathematics. Mathematics. Everything for the teacher! URL: http://www.eosnova.ru/PDF/osnova_3_0_61.pdf

Pavlova, O. A. (2008). Formation of the readiness of the future mathematics teacher for the implementation of moral education of students by means of the history of mathematics (Abstract of PhD thesis). KSPU named after K. E. Tsiolkovsky, Kaluga.

Pavlova, O. A. (2016). Historicization as a means of moral education in teaching mathematics. Mathematics at School, 3, 26-31

Pavlova, O. A. (2018). Basic principles of ensuring the quality of training of future teachers to create conditions in the educational process for students to achieve personal learning outcomes (for example, referring to the potential of mathematical disciplines). Kaluga University Bulletin, 1, 92-95

Pavlova, O. A., \& Chirkova, N. I. (2020). Professionally oriented pedagogical projects as a tool to stimulate the professional self-development of future 
teachers. Nizhny Novgorod Education, 1, 127-134. https:/ / doi.org/10.12737/1998-0744-2020-32-38

Polyakova, T. S. (2017). Nikolay Ivanovich Lobachevsky and mathematical education in Russia. In N.I. Lobachersky and Mathematical Education in Russia. Materials of the International Forum on Mathematical Education (pp. 36-40).

Potapova, S. V., Danilova, I. Y., Prasolov, V. I., Makarova, E. V., \& Kryukova, N. I. (2018). Mythological foundations of ontology. XLinguae, 11(2), 672-685. https://doi.org/10.18355/XL.2018. 11.02 .53

Pyrkov, V. E. (2019). Historical component of school mathematics education. SFU.

Romanov, Yu. V. (2012). Historization of special training of future mathematics teachers as one of the factors for improving the quality of mathematics education. Alma Mater (Bulletin of the Higher School), 5, 51-56.

Sabirova, E., Zakirova, V., Valeeva, R.A., \& Mena, J. (2019). Educational platforms for children in teaching mathematics: Russian Case. In ACM International Conference Proceeding Series (pp. 594599). https:/ / doi.org/10.1145/3362789.3362827

Savvina, O. A. (2019). "All virtues to the assembly" (350th anniversary of the birth of Leonty Filippovich Magnitsky). Mathematics for Schoolchildren, 3, 44-48.

Savvina, O. A., \& Melnikov, R. A. (2019). Transformation of mathematical education in Russia and moral education. In The European Proceedings of Social and
Behavioural Sciences. Complex Research Institute named after Kh. I. Ibragimov (pp. 2806-2812). https:/ / doi.org/10.15405/epsbs.2019.12.04.377

Shabashova, O. V. (1995). Elements of the history of mathematics as a means of forming the general culture of primary school students (on the example of geometry) (PhD thesis). MCPU, Moscow.

Shidlovsky, V. (1912). On the desirability of reporting historical information on the history of mathematics in our secondary school (545, pp. 605-607). Main Directorate of Military Educational Institutions.

Shokhor-Trotsky, S. I. (1892). Aims and means of teaching mathematics from the point of view of general education. Russian School magazine

Sirazetdinov, R. T. (2018). Mathematical models of risk in emergency situations. Vestnik NCBŽD, 4(38), 129134.

Sudakova, Y. E., Kryukova, N. I., Yevgrafova, O. G., Derdizova, F. V., Aleksandrova, N. S. \& Shaidullina, A. R. (2017). Future teachers' communicative culture forming by means of drama-based pedagogy. Man in India, 97(14), 103113. https:/ / doi.org/10.5040/9781350068711.0020

Tavartkiladze, R. Ye., \& Vilenkin, N. Ya. (1985). On the ways of improving the content and teaching of the school mathematics course. TCU.

Valeeva, R. A., \& Bushmeleva, N. A. (2016). Forming analytical competency of higher school students. Mathematics Education, 11(8), 3137-3148.

\section{http://www.ejmste.com}

